\title{
PENINGKATAN EKONOMI KREATIF MELALUI PELATIHAN KETERAMPILAN PEMBUATAN BLANGKON DI KELURAHAN KARANGASEM LAWEYAN SURAKARTA
}

\author{
Sri Hartono ${ }^{1}$, Fithri Setya Marwati ${ }^{2,}$ Sarsono $^{3 *}$ \\ 1,2,3 Universitas Islam Batik Surakarta \\ Sarsono1964@gmail.com
}

\begin{abstract}
ABSTRAK :
Secara umum, industri kreatif adalah kategori usaha yang disematkan untuk usaha-usaha yang menjual produk kreativitas. Besarnya kontribusi industri ini membuat Pemerintah Indonesia mulai menaruh perhatian khusus kepada industri kreatif. Dibuktikan dengan berdirinya Bekraf yang menaungi ekonomi kreatif di Indonesia. Dampak positifnya bagi Indonesia membuat banyak negara juga mulai melirik industri ini. Secara umum, tujuan dari industri kreatif ialah menghasilkan sebuah karya kreatif yang bernilai ekonomi tinggi. Meskipun demikian, perkembangan industri kreatif di indonesia masih jauh lebih kecil dibandingkan dengan negara lain, oleh karena itu dapat dilakukan pembentukan pemetaan berdasarkan subsektor, karena industri kreatif merupakan kegiatan usaha yang berbasis pada kreativitas individu (Darwanto, 2012). Pengabdian Kepada Masyarakat (PKM) ini memiliki tujuan untuk mengembangkan kreativitas anak bangsa guna meningkatkan industry kreatif di Indonesia. Selain itu, program ini sangat berguna sebagai upaya untuk menumbuhkan rasa cinta budaya generasi muda melalui pelatihan ketrampilan pembuatan blangkon yang memiliki nilai budaya Indonesia. Blangkon merupakan salah satu bagian dari pakaian adat khas Jawa yang digunakan untuk penutup kepala bagi pria. Sasaran progam ini adalah pemuda dan pemudi di Kelurahan Karangasem Laweyan Surakarta yang belum bekerja. Metode pelaksanaan dilakukan dengan memberikan pelatihan dan praktik serta tanya jawab terkait dengan proses pembuatan blangkon dan strategi pemasaran blangkon. Pelaksanaan pelatihan meliputi teori dan praktek pembuatan blangkon dan manajemen selama. Pelatihan ini melibatkan narasumber dan tim pelaksana Pengabdian Kepada Masyarakat dari Fakultas Ekonomi Manajemen Universitas Islam Batik Surakarta. Dari pelatihan PKM dalam pembuatan blangkon ini keluaran yang diharapkan adalah sebagai berikut: (1) Dengan tercapainya pelatihan bagi masyarakat dalam usaha pembuatan blangkon ini diharapkan para peserta dapat mendirikan usaha pembuatan blangkon untuk menambah pendapatan ekonomi dan juga melestarikan tradisi budaya Jawa, (2) Mendorong penciptaan lapangan kerja baru yang mampu menampung tenaga kerja yang terampil dan terdidik, dan (3) Dari program ini diharapkan memberikan pengembangan ketrampilan bagi generasi muda untuk terus mengembangkan kreativitasnya.
\end{abstract}

Kata Kunci: Ekonomi Kreatif, Pelatihan Ketrampilan, Blangkon

\section{IMPROVEMENT OF CREATIVE ECONOMY THROUGH TRAINING OF BLANGKON MAKING SKILLS IN KARANGASEM LAWEYAN SURAKARTA}

\begin{abstract}
In general, the creative industry is a business category that is attached to businesses that sell creative products. The large contribution of this industry has made the Indonesian government began to pay special attention to the creative industry. It is proven by the establishment of Bekraf which oversees the creative economy in Indonesia. Its positive impact on Indonesia has made many countries also start to look at this industry. In general, the goal of the creative industry is to produce a creative work of high economic value. Nevertheless, the development of the creative industry in Indonesia is still much smaller than that of other countries, therefore it is possible to establish a mapping based on sub-sectors because the creative industry is a business activity based on individual creativity (Darwanto, 2012). This Community Service (PKM) has the aim of developing the creativity of the nation's children to improve the creative industry in Indonesia. In addition, this program is very useful as an effort to foster a sense of love for the culture of the younger generation through training in making blangkon skills that have Indonesian cultural values. Blangkon is a part of Javanese traditional clothing that is used to cover the head for men. The target of this program is youth and women in Karangasem Laweyan Village, Surakarta who have not worked. The implementation method is carried out by providing training and practice as well as questions and answers related to the
\end{abstract}


process of making blangkon and blangkon marketing strategies. Implementation of the training includes theory and practice of making blangkon and management during. This training involved resource persons and the Community Service implementation team from the Faculty of Economics and Management, Islamic University of Batik Surakarta. From the PKM training in making blangkon, the expected outputs are as follows: (1) With the achievement of training for the community in the business of making blangkon, it is hoped that the participants can establish a business of making blangkon to increase economic income and also preserve Javanese cultural traditions, (2) Encouraging creation of new job opportunities that can accommodate skilled and educated workforce, and (3) This program is expected to provide skill development for the younger generation to continue to develop their creativity.

Keywords: Creative Economy, Skills Training, Blangkon

\section{PENDAHULUAN}

Dalam kehidupan yang dinamis dan penuh perubahan ini, kreativitas sangat diperlukan untuk terus bisa berinovasi dan belajar. Lewat kreativitas, dihasilkan berbagai macam produk dan jasa baru yang meningkatkan perekonomian dan kualitas hidup manusia. Ekonomi kreatif berkaitan erat dengan industri kreatif. Namun ekonomi kreatif memiliki cakupan yang lebih luas dari industri kreatif. Ekonomi kreatif merupakan ekosistem yang memiliki hubungan ketergantungan antara rantai kreatif (creative value chain), lingkungan pengembangan (nature environment), pasar (market) dan pengarsipan (archieving).

Menurut United Nations Conference on Trade and Development (UNCTAD, 2018), ekonomi kreatif adalah sebuah evolusi konsep berdasarkan aset kreatif yang berpotensi menghasilkan pertumbuhan dan perkembangan ekonomi. Roberta Comunian dan Abigail Gilmore dalam Higher Education and the Creative Economy (2016) menjelaskan ekonomi kreatif adalah konsep ekonomi baru yang mengintensifkan informasi dan kreativitas dengan mengandalkan ide dan pengetahuan sebagai faktor produksi utama. John Howkins (2001) mendefinisikan ekonomi kreatif sebagai ekonomi yang menjadikan kreatifitas, budaya, warisan budaya dan lingkungan sebagai tumpuan masa depan. Konsep ini kemudian dikembangkan oleh Richard Florida (2008) dalam bukunya The Rise of Creative Class dan Cities and Creative Class yang menyebutkan bahwa manusia pada dasarnya adalah kreatif, apakah ia seorang pekerja di pabrik kacamata atau seorang remaja di gang senggol yang sedang membuat musik hip-hop, perbedaannya terletak pada statusnya. Sedangkan menurut Kementrian Pariwisata dan Ekonomi Kreatif, ekonomi kreatif adalah penciptaan nilai tambah yang berbasis ide yang lahir dari kreatifitas sumber daya manusia (orang kreatif) dan berbasis ilmu pengetahuan, termasuk warisan budaya dan teknologi (Kemenparekraf, 2014).

Konsep ekonomi kreatif ini lebih dikenal dengan istilah industri kreatif karena industri kreatif merupakan bagian dari ekonomi kreatif itu sendiri. Menurut United Kingdom Departement Culture, Media and Sport (DCMS, 2010), industri kreatif adalah berbagai hal yang memerlukan kreativitas, keterampilan, dan bakat yang dilakukan untuk penciptaan kesempatan kerja dan kesejahteraan melalui eksploitasi properti intelektual. Kegiatan industri kreatif ini mencakup iklan, arsitektur, pasar seni dan barang antik, kerajinan, desain, fashion, film dan video, musik, seni pertunjukan, percetakan, software, televisi dan radio serta video dan game komputer.

Sedangkan berbicara mengenai ekonomi kreatif basis budaya, Geertz (2010) menekankan kebudayaan sebagai sekumpulan ide dan proses kreatif dari akal budi yang diwariskan kemudian mewarnai kehidupan sebuah kemasyarakatan. Proses kreatif dari akal budi jika diimplementasikan terhadap suatu bidang usaha akan menghasilkan suatu produk yang kreatif. Rianse dkk. (2013) mendefinisikan budaya merupakan pola hidup menyeluruh, bersifat kompleks, abstrak serta luas yang terpolarisasi dalam suatu citra yang khas, yang berarti setiap produk industri kreatif basis budaya akan mempunyai ciri yang khas yang unik dan berbeda dari yang lain. Ekonomi Kreatif Berbasis Seni dan Budaya terdiri dari: Pasar Barang Seni, Kerajinan, Film, Video dan Fotografi, Musik, Seni Pertunjukan.

Masalah yang muncul di sini adalah laju pertumbuhan industri kreatif di Indonesia masih tergolong rendah apabila dibandingkan dengan negara-negara lainnya seperti Malaysia, Singapura, 
Jepang, China, dan Jerman. Berdasarkan hasil riset antara Badan Ekonomi Kreatif (Bekraf) dan Badan Pusat Statistik (BPS) pada tahun 2016, tercatat ekonomi kreatif memberikan kontribusi kepada pertumbuhan ekonomi nasional sebesar 922.59 miliar rupiah atau sebesar 7.44 persen terhadap Produk Domestik Bruto (PDB) nasional. Banyak bukti empiris yang mendukung bahwa industri kreatif membawa dampak terhadap PDB melalui subsektor industri kreatif dan menciptakan bentuk baru tata kelola industri budaya (Fahmi et al. 2016; Daubaraite dan Startiene 2015; United Nations Development Programme 2013). Industri kreatif mempunyai beberapa permasalahan terkait dengan perkembangannya di Indonesia. Pertama, berdasarkan data BPS dan Bekraf (2017), pertumbuhan PDB industri kreatif di Indonesia pada tahun 2016 hanya terealisasi sebesar 4.95 persen dari yang ditargetkan sebesar 5.21 persen. Sasaran pembangunan ekonomi kreatif yang ditargetkan sebesar 12 persen dalam Rencana Pembangunan Jangka Menengah Nasional (RPJMN) 2019, baru terealisasi sebesar 7.44 persen di tahun 2016. Perkembangan ekonomi kreatif di Indonesia juga terdapat beberapa masalah seperti penyebaran sumber daya yang belum merata, sulit menembus pasar internasional dan mendapatkan sumber pendanaan usaha, minimnya kontribusi dari pekerja yang memiliki pendidikan tinggi, serta masalah lainnya.

Pada era modern ini banyak generasi muda sebagai penggerak bagi era ekonomi kreatif. Generasi ini percaya bahwa mereka sebagai penggerak era ekonomi, apa yang meraka sukai, atau sebagai bisnis dan harus mempunyai inovasi atau ide-ide baru yang belum ada saat ini dan ide-ide tersebut harus kreatif, inovatif dan sangat unik. Pemuda adalah generasi yang diharapkan memiliki kemampuan berfikir kritis, inovatif, dan kreatif dalam menghadapi tantangan dan persoalan bangsa. Dengan semangatnya yang besar diharapkan mampu menjadi penerus perjuangan bangsa. Dalam sejarah bangsa Indonesia tidak lepas dari peran aktif pemuda dalam menyalurkan ide dan gagasan kritis dan inovatif. Generasi muda menjadi ujung tombak perjuangan merubah kondisi bangsa ke arah yang lebih baik. Pemuda dikategorikan sebagai "agent of social change" Maka dari itu pemuda dengan Mengedepankan kreativitas dan inovasi dalam pembangunan nasional untuk mengoptimalkan berbagai potensi kekayaan yang dimilikinya merupakan aset suatu daerah.

Untuk bisa menjadi pelaku ekonomi kreatif maka generasi muda harus memilki berbagai macam kemampuan, kreativitas dan inovatif. Generasi muda perlu mengasah daya nalar dan kreativitasnya agar nantinya berbagai konsepsi terkait peningkatan ekonomi UKM bisa diberdayakan masyarakat. Dlam hal ini, untuk mendukung pengembangan kreativitas generasi muda pada industri kreatif, dibutuhkan adanya peran dari berbagai pihak, terutama para akademisi untuk memberikan motivasi dan pelatihan kepada para pemuda dan pemudi generasi bangsa agar dapat lebih mengembangkan kreativitasnya untuk meningkatkan pertumbuhan industri kreatif. Sebagai bentuk atau wujud dukungan terhadap pemuda dan pemudi generasi bangsa untuk memberikan motivasi berwirausaha dan ilmu pengetahuan terkait industri kreatif, maka tim penyelenggara Pengabdian Kepada Masyarakat (PKM) dari Fakultas Ekonomi pada Universitas Islam Batik Surakarta menyelenggarakan program Pengabdian Kepada Masyarakat yang berjudul "Peningkatan Ekonomi Kreatif Melalui Pelatihan Keterampilan Pembuatan Blangkon Di Kelurahan Karangasem Laweyan Surakarta".

\section{METODE PELAKSANAAN}

Sasaran dari Pengabdian Kepada Masyarakat (PKM) ini adalah sejumlah pemuda dan pemudi di Kelurahan Karangasem Laweyan Surakarta, terutama bagi yang belum memiliki pekerjaan dan hanya lulusan SMP atau SMA serta memiliki minat belajar usaha pembuatan blangkon.

Metode pelaksanaan kegiatan ini dilakukan dengan memberikan pelatihan/workshop plus praktik/latihan serta tanya jawab terkait dengan proses pembuatan blangkon dan strategi pemasarannya. Kegiatan seperti ini dirasakan sangat perlu untuk mengembangkan ide dan kreativitas para pemuda dan pemudi di wilayah setempat. Adapun cara memperoleh peserta dari pelatihan ini adalah sebagai berikut:

a. Survey lokasi dan penentuan tempat yang akan digunakan untuk pelatihan.

b. Perekrutan peserta program dengan persyaratan sebagai berikut: 
1) Masyarakat yaitu pemuda dan pemudi yang belum bekerja atau memiliki usaha.

2) Mempunyai kemauan dan kemampuan berwirausaha.

3) Disiplin tinggi, menaati peraturan selama pelatihan.

4) Keinginan kuat untuk mendirikan usaha.

c. Sosialisasi program untuk menarik minat masyarakat untuk bisa dijadikan sebagai peserta program.

\section{HASIL DAN PEMBAHASAN}

Program Pengabdian Kepada Masyarakat ini telah sukses dilaksanakan dan berjalan lancar sesuai dengan yang direncanakan. Pelaksanaannya dilakukan pada bulan September 2019 mulai pukul 09.00 WIB, yang bertempat di Kelurahan Karangasem Laweyan Surakarta. Bentuk kegiatan pengabdian masyarakat ini adalah penyuluhan kepada pemuda di kelurahan karangasem laweyan surakarta dengan ceramah pokok dan training dengan bahasan mengenai pembuatan blangkon dan dengan mendatangkan narasumber.

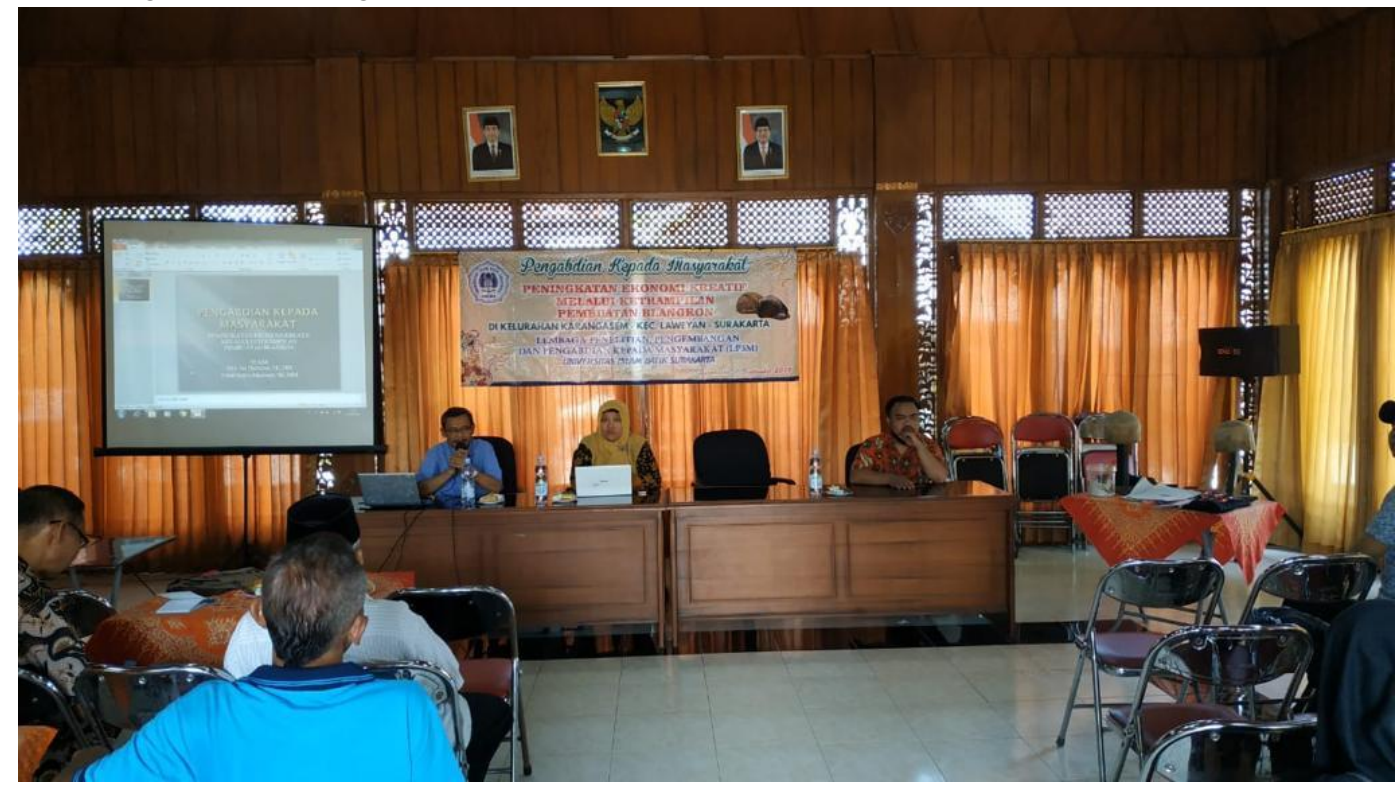

Gambar1 Pembukaan Kegiatan Pelatihan

Kegiatan Pengabdian Masyarakat ini melibatkan narasumber dan tim pelaksana dari Universitas Islam Batik Surakarta, yaitu Drs. Sri Hartono, SE. M.Si dan Dr. Sarsono, SE,M.Si yang menyampaikan materi terkait dengan Pemasaran, Fithri Setya Marwati, SE, MM yang menyampaikan materi terkait dengan Ekonomi Kreatif dan Pengetahuan tentang Blangkon. Materi tersebut diberikan untuk penciptaan gagasan mengenai ekonomi kreatif yang merupakan salah satu cara untuk membuka peluang baru di industri. Pemberian pengetahuan terkait dengan pemasaran dan ekonomi kreatif ini diharapkan dapat menambah wawasan bagi para pemuda dan pemudi di wilayah terlaksananya kegiatan Pengabdian Kepada Masyarakat ini. 


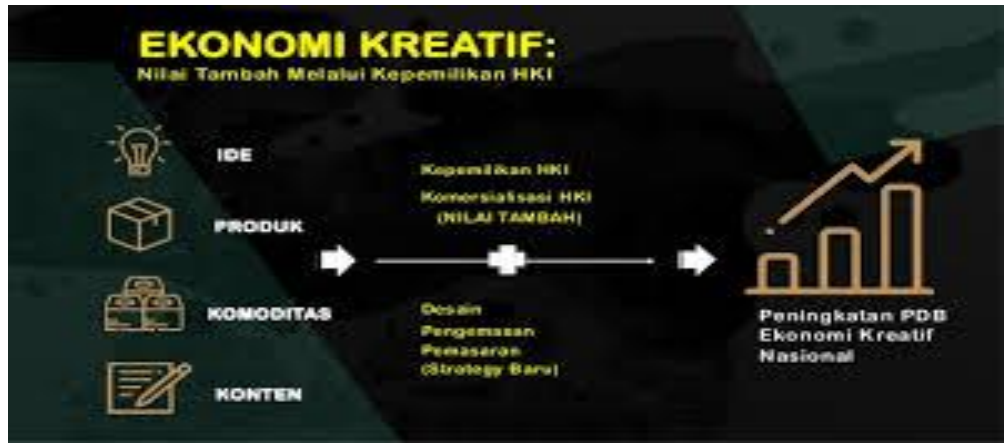

Gambar 2 Pembahasan Materi Ekonomi Kreatif

Ekonomi kreatif adalah suatu konsep ekonomi diera sekarang. Dimana kegiatan ekonomi lebih mengintensifkan informasi dan kreativitas dengan mengandalkan ide dan pengetahuan dari sumber daya manusia sebagai faktor produksi yang utama. Beberapa ciri ekonomi kreatif diantaranya berbasis pada ide dan juga gagasan, pengembangannya bersifat terbuka dan unlimited, merupakan hasil kreasi intelektual, mampu membuat relasi dengan berbagai pihak, konsep yang dibangun bersifat sementara dan mudah tergantikan.

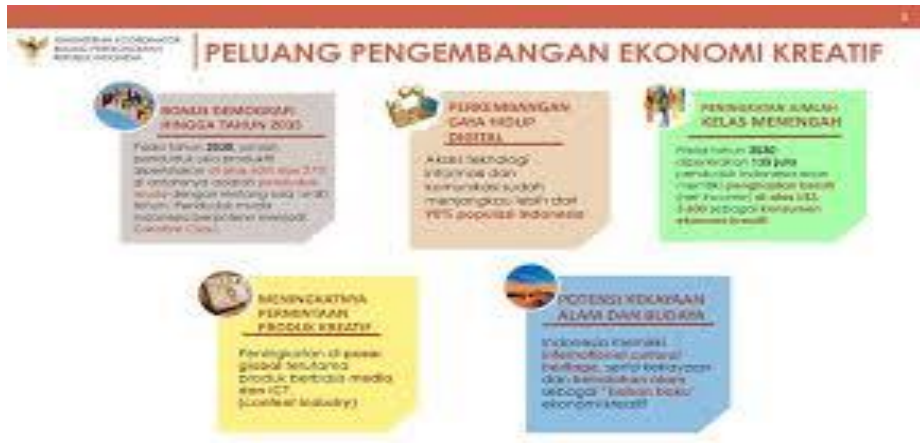

Gambar 3 Peluang Pengembangan Ekonomi Kreatif

Peluang pengembangan ekonomi kreatif di Indonesia terletak pada kekayaan kearifan lokal Indonesia, salah satunya adalah sumber daya budaya yang bersumber dari adanya interaksi sosial antar masyarakat. Dalam hal ini adalah pembuatan blangkon sebagai salah satu bagian dari pakaian adat khas Jawa yang digunakan untuk penutup kepala bagi pria sebagai pelindung dari sengatan matahari atau udara dingin. Awalnya blangkon terbuat dari kain iket atau udeng berbentuk persegi empat bujur sangkar, berukuran kurang lebih $105 \mathrm{~cm}$ x $105 \mathrm{~cm}$. Kain yang kemudian dilipat dua menjadi segitiga dan kemudian dililitkan di kepala dengan cara dan aturan tertentu. Mengenakan iket dengan segala aturannya ternyata tidak mudah dan memerlukan waktu, maka timbullah gagasan seiring dengan kemajuan pemikiran orang dan seni untuk membuat penutup kepala yang lebih praktis, yang kemudian dikenal dengan nama blangkon.

Keberadaan blangkon sebagai hasil budaya Jawa sebenarnya tidak sekedar sebagai pelengkap berpakaian saja namun memiliki makna yang dalam. Blangkon memiliki berbagai motif kain batik, seperti: motif gurda, kawung, truntum, wahyu tumurun, sido mukti dan sebagainya. Beragamnya motif blangkon sesuai dengan beragamnya motif kain batik tradisional di Jawa. Setiap motif memiliki makna dan aturan tertentu dalam pemakaianya. 


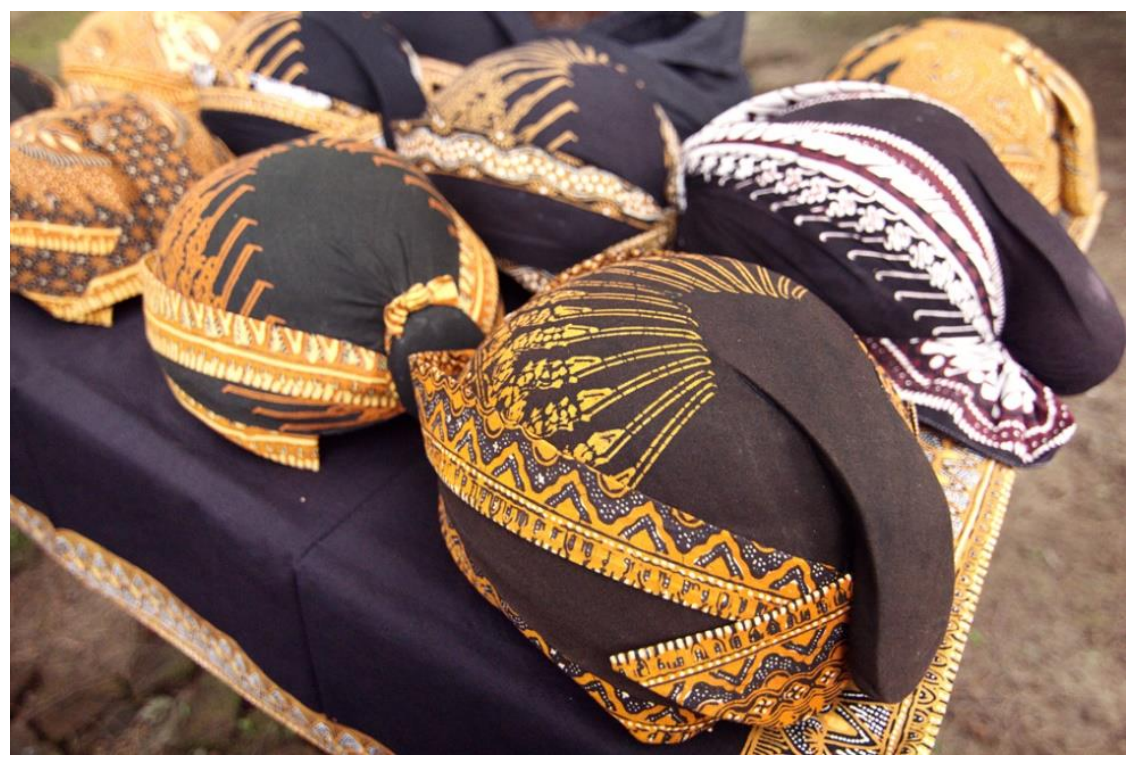

Gambar 4 Pengetahuan Tentang Blangkon

Sebelum menjadi blangkon, kain dipakai dengan cara jingkengan. Blangkon merupakan barang jadi dari iket yang diwiru. Lalu dibulatkan dengan cetakan yang namanya klebut. Cara menggunakan blangkon harus diukur lingkar kepala di atas alis dan lingkar di kedua telinganya. Blangkon Solo dikenal mulai Pakubowono III, setelah terjadinya Perjanjian Giyanti. Sebelum itu blangkon Solo seperti memiliki bentuk seperti blangkon Jogja. Setelah perjanjian Giyanti, ada revolusi kebudayaan besar yang menyebabkan Pakubuwono III membuat beragam blangkon. Jika Jogja hanya memiliki 1 model blangkon, Solo mempunyai 6 model blangkon.

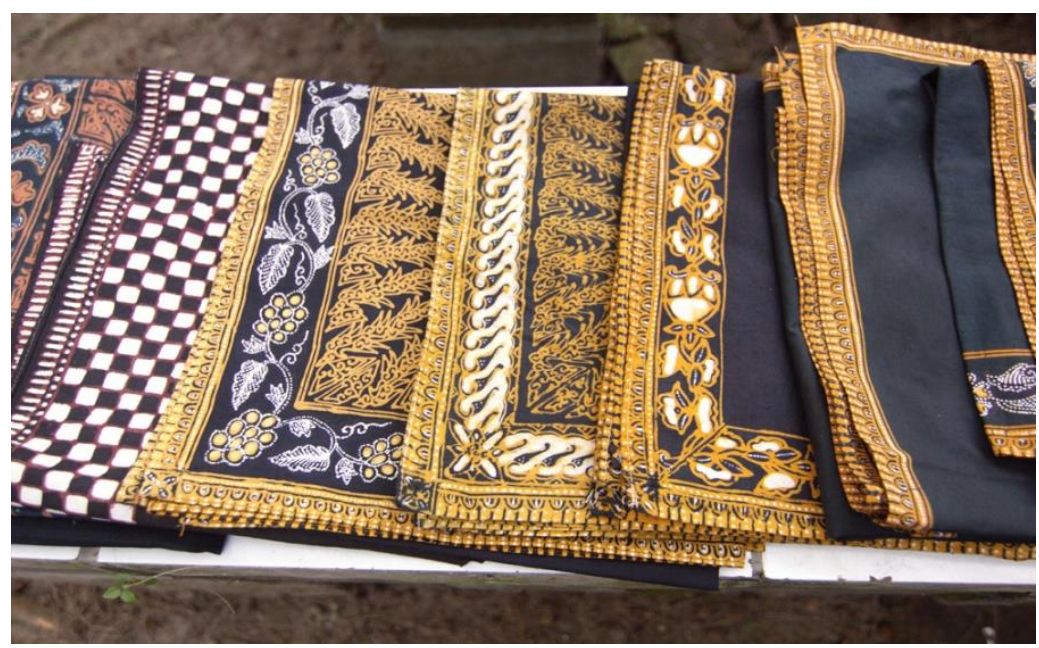

Gambar 5 Pengetahuan tentang Motif Blangkon

Untuk materi berikutnya dari Bapak Drs Sri Hartono, SE., M.Si dan Dr. Sarsono, SE.M.Si dengan bahan presentasi yang bertema "Pemasaran" yang disampaikan kurang lebih 1 jam juga. Berikut adalah contoh muka bahan presentasinya yang dapat dilihat dapat gamber 6 dan 7 berikut ini. 


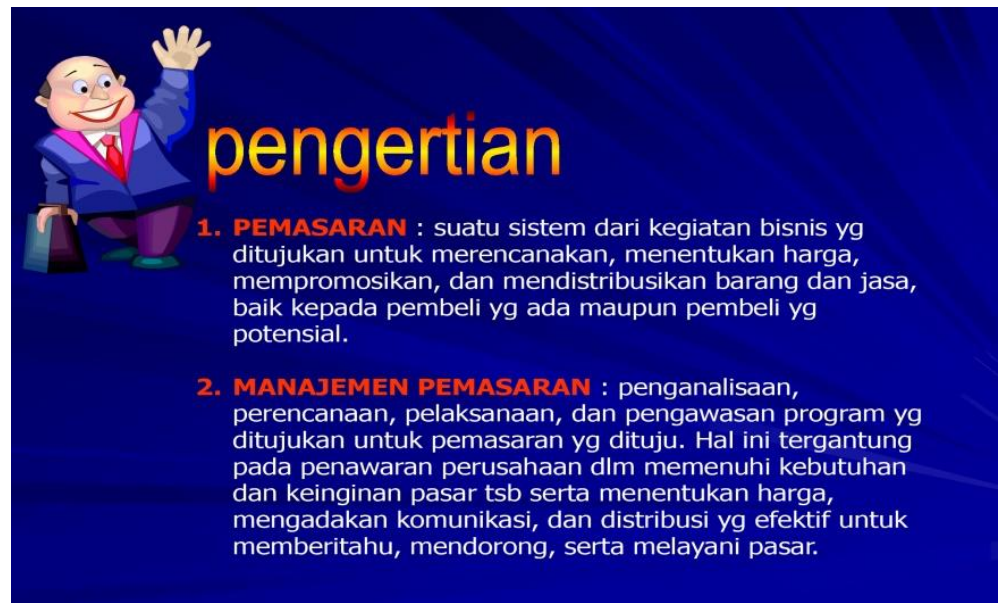

Gambar 6. Materi Pemasaran

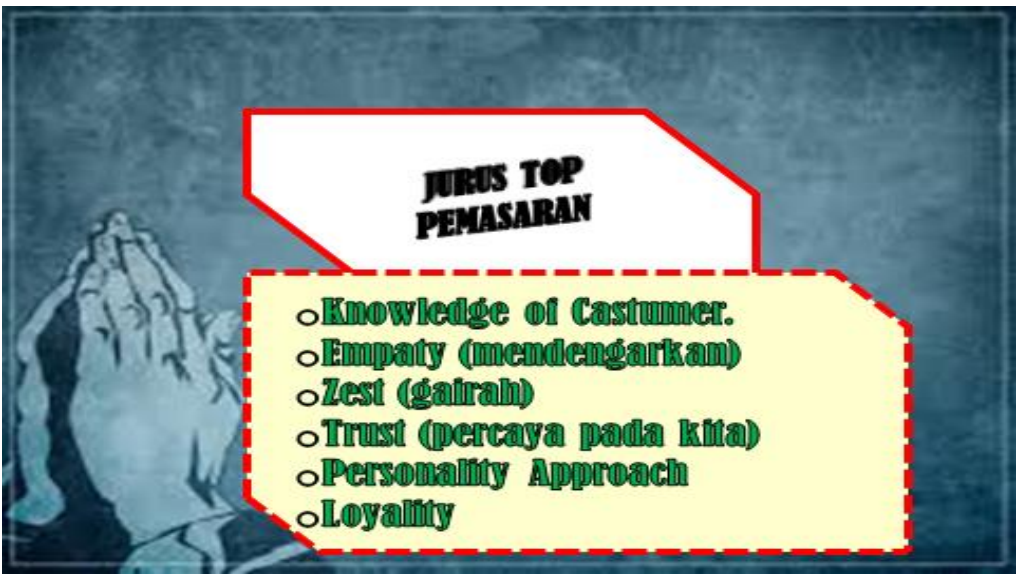

Gambar 7 Materi Pemasaran

Perancangan strategi pemasaran produk industri kreatif perlu dilakukan untuk setiap kategori produk tersebut, dikarenakan produk-produk tersebut memiliki karakteristik berbeda mulai dari fungsi dan pasar penggunanya. Misalnya, strategi pemasaran untuk produk fesyen tentu berbeda dengan produk periklanan; untuk produk kerajinan tentu berbeda dengan layanan komputer dan piranti lunak; dan untuk musik tentu berbeda dengan jasa riset dan pengembangan. Hal tersebut perlu dibedakan, agar efektifitas pemasaran produk industri kreatif optimal.

Kemudian untuk pelaksanaan pelatihan meliputi teori dan praktek pembuatan blangkon dan manajemen, sebagai berikut:

Tabel 1. Pelaksanaan Kegiatan Pelatihan Blangkon

\begin{tabular}{|c|c|c|c|}
\hline No & Materi & Tentor/ Instruktur & Pokok Bahasan \\
\hline 1. & Teori & $\begin{array}{l}\text { a. Instruktur } \\
\text { b. Tim PKM }\end{array}$ & $\begin{array}{l}\text { a. Teori Pembuatan } \\
\text { blangkon proses awal } \\
\text { sampai akhir. }\end{array}$ \\
\hline & & & $\begin{array}{l}\text { b. Teori manajemen } \\
\text { usaha. }\end{array}$ \\
\hline 2. & Praktek & $\begin{array}{l}\text { a. Instruktur } \\
\text { b. Tim PKM }\end{array}$ & $\begin{array}{ll}\text { a. } & \text { Teori Pembuatan } \\
\text { blangkon proses awal } \\
\text { sampai akhir. (jadi) } \\
\text { b. Pengemasan Produk }\end{array}$ \\
\hline
\end{tabular}


Untuk materi-materi pembuatan blangkon, adalah sebagai berikut.

Materi yang disampaikan oleh tim pelaksana PKMM adalah pembuatan blangkon. Pelatihan didahului dengan pengenalan dan dasar pelatihan pembuatan blangkon. Hal ini bertujuan membuka wawasan berfikir peserta pelatihan bahwa dari satu bahan bias dihasilkan sesuatu yang bernilai ekonomi dan seni.

Pemakaian blangkon disesuaikan menurut adatnya, misal blangkon bermotif byur dipakai khusus dengan kain panjangnya/kain jaritannya. Motif wahyu temurun sebaiknya juga memakai kain jarit wahyu temurun. Orang dapat memakai blangkon modang motif ompak jika merasa sesorang tersebut belum memiliki "ilmu" yang memadai. Tingkatan di bawahnya ada jenis wulung kemodo hanya pinggirnya saja. Jika seseorang menganggap dirinya tidak mampu maka blangkon yang dikenakan adalah jenis blangkon wulung.

Pembuatan blangkon melalui berbagai proses, antara lain pemilihan bahan motif kain, pengukuran, dan model. Bahan kain untuk pembuatan blangkon merupakan kain bermotif batik. Setelah ditentukan motif maka pembuatan disesuaikan dengan ukuran si pemakai. Agar cara pemakaiannya praktis maka pembuatannya diatur sedemikian rupa dengan penguat dan pengeras sehingga ketika dilepas tidak terurai. Proses tersebut selesai kurang dari 30 menit dan harus dijemur di bawah sinar matahari yang terik selama 3-4 jam. Proses terakhir adalah dijahit agar lebih kuat. Alat-alat yang digunakan antara lain tang, jarum, sumpit, congkeng. Sedangkan bahan yang dibutuhkan berupa jarit, kardus, dan lem. berikut:

Dalam pembuatan kerajinan pembuatan blangkon ini diperlukan alat dan bahan sebagai

a. Kain yang bermotif / kain batik berbentuk iket atau udeng berbentuk persegi empat bujur sangkar. Ukurannya kira-kira selebar $105 \mathrm{~cm}$ x $105 \mathrm{~cm}$.

b. Klebot atau model kepala yang terbuat dari kayu/cetakan blangkon.

c. Plastik kemasan.

d. Kain alas, karton, lem, benang jahit, dan gunting.

Untuk proses kegiatan pelatihan pembuatan blangkon pada Pengabdian Kepada Masyarakat ini adalah sebagai berikut:
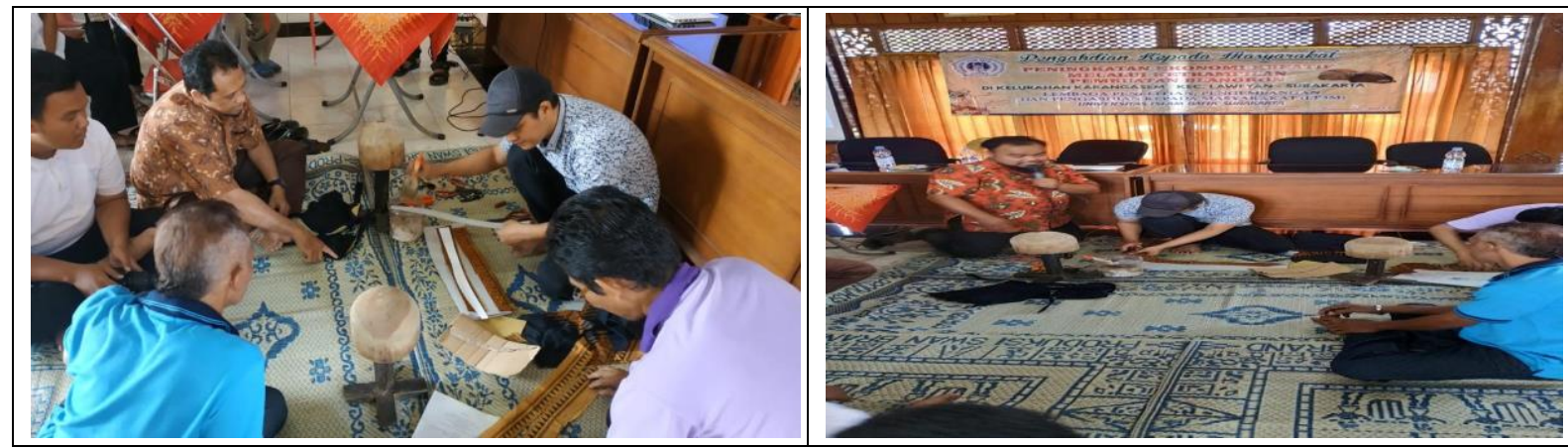

Gambar 8 Kegiatan Pelatihan Pembuatan Blangkon 


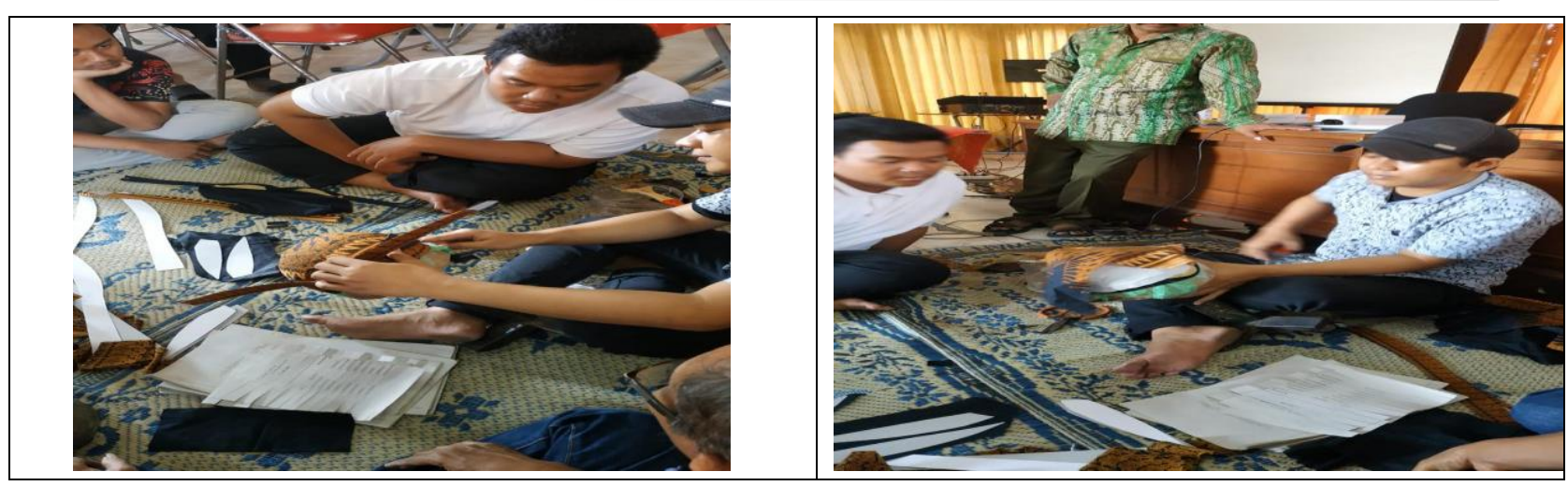

Gambar 9 Kegiatan Pelatihan Pembuatan Blangkon

Program pelatihan pembuatan blangkon dalam Pengabdian Kepada Masyarakat ini telah di ikuti oleh seluruh peserta dari awal hingga selesai dan telah berjalan dengan baik dan lancar. dari:

Evaluasi penguasaan materi pelatihan oleh peserta program dimana evaluasi ini terdiri

a. Evaluasi penjelasan teori dan praktek pembuatan blangkon mulai dari proses awal sampai akhir.

b. Penilaian hasil penugasan mandiri maupun kelompok (hasil praktek).

c. Penilaian pembuatan blangkon.

d. Evaluasi studi kelayakan usaha (proposal rencana usaha) yang disusun oleh peserta program dan diuji melalui presentasi.

Berdasarkan hasil evaluasi dari pelaksanaan program pelatihan pembuatan blangkon, motivasi dan minat peserta pelatihan untuk berwirausaha tergolong tinggi dan keberhasilan pelatihan pembuatan blangkon oleh peserta cukup tinggi. Peserta dapat mengikuti proses pembuatan blangkon, mempraktekkan pembuatan blangkon, dan mempresentasikan hasil karya blangkon.

\section{KESIMPULAN}

Kesimpulan yang dapat ditarik dari kegiatan Pengabdian Kepada Masyarakat (PKM) melalui program pelatihan ketrampilan pembuatan blangkon di Kelurahan Karangasem Laweyan Surakarta adalah dengan tercapainya pelatihan bagi masyarakat dalam usaha pembuatan blangkon ini, para peserta dapat mendirikan usaha pembuatan blangkon untuk menambah pendapatan ekonomi dan juga melestarikan tradisi budaya Jawa serta terciptanya lapangan kerja baru yang mampu menampung tenaga kerja yang terampil dan terdidik dan juga memberikan pengembangan ketrampilan bagi para pemuda dan pemudi di wilayah setempat untuk berwirausaha.

\section{DAFTAR PUSTAKA}

Badan Pusat Statistik (BPS) diakses dari http://www.bps.go.id/, diakses pada tanggal 2 Februari 2019 pada jam 20.20 WIB.

Darwanto. (2012). Peran Entrepreneurship Dalam Mendorong Pertumbuhan. Ekonomi Dan Peningkatan Kesejahteraan Masyarakat.

DCMS.Creative Industries Mapping Document.London: Department of Culture, Media and Sport. (2001). Dikutip dari Jurnal The Entrepreneurial Dimension of the Cultural and Creative Industries. HKU, Hogeschool Voor de Kunsten Utrecth (2010) : hal. 8 - 9.

Florida, Richard (2008). "The Rise of Creative Class" dan "Cities and the Creative Class", UK Department of Culture, Media and Sport, 1999.

Geertz, Cliffortz, (2010), The Interpretation of Cultures, New York: Basic Books Inc. 
Geertz, Clifford, (1992), Kebudayaan dan Agama, diterjemahkan oleh F. Budi Hardiman dari The Interpretation of Cultures, Yogkakarta: Kanisius.

Geertz, Clifford, (1999), After The Fact: Dua Negeri, Empat Dasawarsa, Satu Antropolog, diterjemahkan oleh Landung Simatupang dan Hairus Salim dari After The Fact: Two Countries, Four Decades, One Antropologits, Yogyakarta: LKiS.

Howkins, John. (2001). The Creative Economy. Inggris: Penguins Book.

Resnstra Kemenparekraf 2012-2014, tersedia di (http://www.kemenpar.go.id/, diakses pada 1 Januari 2017).

Rianse, Usman dan Abdi. (2011). Metodologi Penelitian Sosial dan Ekonomi: Teori dan Aplikasi. Bandung: Alfabeta.

United Nations Conference on Trade And Development. (2018). Creative Economy Outlook 2018.

United Nations Conference on Trade And Development. Value Values and shares of creative industries related goods exports https://unctadstat.unctad.org/ wds/TableViewer/ tableView.aspx?ReportId=14772 diakses 8 April 2019. 